\title{
Aspects of political theology in the spiritual autobiography of Nicolas Berdiaev
}

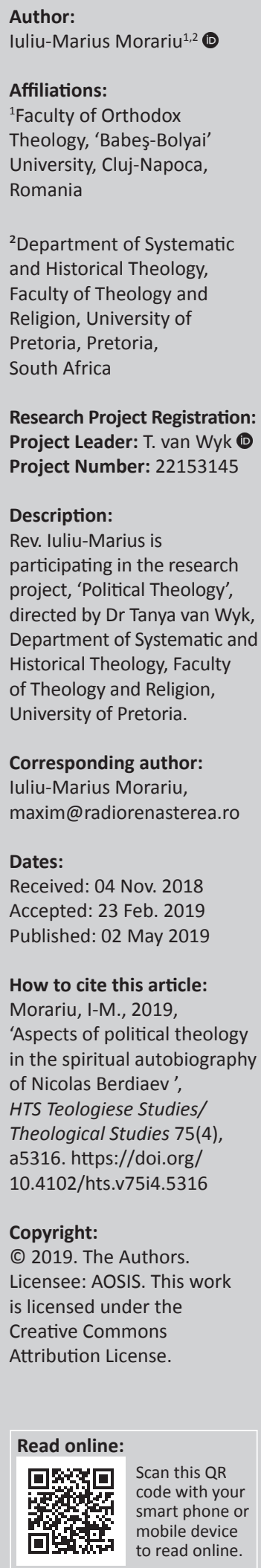

Author:

Affiliations:

${ }^{1}$ Faculty of Orthodox

Theology, 'Babeş-Bolyai'

University, Cluj-Napoca,

Faculty of Theology and

eligion, University of

Pretoria, Pretoria

Research Project Registration:

Project Leader: T. van Wyk (D)

Description

Rev. Iuliu-Marius is

directed by Dr Tanya van Wyk

Department of Systematic and

of Theology and Religion,

University of Pretoria.

Corresponding author:

Iuliu-Marius Morariu,

Dates:

Received: 04 Nov. 2018

Accepted: 23 Feb. 2019

How to cite this article:

Morariu, I-M., 2019

'Aspects of political theology

of Nicolas Berdiaev',

HTS Teologiese Studies/

Theological Studies 75(4),

a5316. https://doi.org/

$102 /$ hts.v75i4.5316

Copyright:

is licensed under the

Creative Commons

Attribution License.

to read online.
Despite its importance for the understanding of ideas and the genesis of Nicholas Berdiaev's works, his spiritual autobiography, written at the end of his life, has not been fructified enough by contemporary research until today. Therefore, this research aims at bringing it into attention and emphasising the aspects of political theology it contains. The author investigates elements such as the philosopher's eschatological notes, his conception about freedom and slavery or about the superior human condition, trying to see how they influence his representation of political theology. Moreover, he links his political and religious attitudes, in an attempt not only to identify the context in which his ideas regarding this topic were born and to find influences of the context in which he lived, but also to emphasise the contemporary dimension of his way of thinking and the place the topic holds in his spiritual autobiography. For this purpose, he also uses the works of the aforementioned philosopher, the book reviews and dictionary entries dedicated to his autobiography, as well as the books, articles and reviews dedicated to Berdiaev and his work, starting from his lifetime and up to these days.

Keywords: Spirituality; Freedom; Eschatology; Russian Revolution; Communism.

\section{Introduction}

For both the theological and philological space, the Russian Nicolas Berdiaev, an important personality, has left valuable works to posterity. Spirit and Freedom (Berdiaev 2009) and A New Middle Age (Berdiaev 2001), translated into 17 languages, are just two examples. Among the books that he published, an important, yet little ${ }^{1}$ fructified one is definitely his autobiography (Berdiaev 1992a, 1998), a book that can clearly be considered unfinished (Vadimov 1998:9). Written as a philosophical book, which is also filled with information related to his spiritual life and his road to God, who represents the accomplishment of an eschatological freedom, Berdiaev's autobiography is important for mystical spirituality, history, philosophy and sociology, among other topics.

Besides information on the inner metamorphosis of the author and on the history of Russia of his time, the work also contains interesting information on political theology. More than in the spiritual autobiography of Saint John of Kronstadt (Morariu 2018b:1-5), also a Russian author, or in the autobiography of the Swedish diplomat Dag Hammarsjkold (Morariu 2017:129-133, 2018a:1-5), in Berdiaev's work we can investigate aspects related to political theology and to its meanings. This is not to surprise us if we take into account the fact that he comes from a space and a time when Tolstoy ${ }^{2}$ and Dostoyevsky (Dostoievski 1997) were famous authors, that he was influenced by their way of thinking (Berdiaev 1992a) and also that the author was at first a Kantian Marxist (Audi 2015:97), being even imprisoned for his ideas (Bompiani University 2006:1187; Craig 1998:26). Still, it must be mentioned that despite the influences of the aforementioned writers, his own way of thinking is original and different from theirs, expanding on aspects like religion and spirituality and their relationship with philosophy or reality, which are just mentioned in the others works. Given the relevance of his ideas and the fact that, until now, this topic has not been investigated by researchers, we shall try, in this research, to present the main aspects of political theology that transpire from the spiritual-philosophical autobiography of the Russian author. To accomplish this task, we shall resort to other works that refer to such a topic, to the philosopher's autobiographical works and to the writings dedicated to him throughout time.

1.Presented only in a few book reviews and having just short references in the works dedicated to him. See, for example, Casañas (1982:282-288), Louth (2015:60-76); Lubas-Bartoszyńska (2010:55-75).

2.Famous for his political ideas related to socialism. For more information about his ideas, see Tolstoy (1904, 1907, 2008, 2013, 2016, 2017). 


\section{Aspects of political theology in the spiritual autobiography of Nicolas Berdiaev}

Before speaking about the aspects of political theology that can be found in the spiritual autobiography of Berdiaev, one must clearly take into account the fact emphasised by the author at the beginning of his memoires, namely, that he was a man who had gone through three wars and two revolutions and had been imprisoned four times (Berdiaev 1992a:10). His revolutionary character, connected to his family heritage, ${ }^{3}$ almost explains why he got in touch with authors like Rousseau $(1969)$, Gide $(1946,1948)$ or Augustine (1991), who also influenced him in writing the text that we set off to investigate. Moreover, it influenced him as a young person to support Marxism (Pezzimenti 2013:272) and its doctrine to embrace Communism for a while (Berdiaev 1992a:272).

His attitude towards politics starts with and converges towards freedom. In fact, his entire system of thinking is circumscribed by this keyword (Damian 2010:205-206), as he shows in his spiritual autobiography:

The spirit of freedom is innate to me: through my roots and pathos, I am an emancipator. To the exterior world, I oppose the interior one. (Berdiaev 1992a:34)

According to him, this freedom starts from God's wish. In other words, it is connected to providence. ${ }^{5}$ Consequently, life is seen by him as a test of freedom, in which man must gain victory over temptations (Berdiaev 1992a:67). The right use of freedom helps surpass inequality (Berdiaev 1976:25-28), which is an important aspect from the political point of view.

As we have already mentioned, before speaking and writing about the way in which politics and theology can interfere and develop points of convergence and before becoming a philosopher who theorised on this topic, he experienced Russian political life before and during the revolution in a very committed way. If his closeness to Communism brought him several imprisonments, his criticism of it after the revolution made him to be part of the phenomenon called 'the exile of intelligentsia' (Chamberlain 2007). As Celline Marange shows in the foreword of an anthology book containing some of his theological studies:

\footnotetext{
3.According to him: 'It is necessary to mention some hereditary characteristics of our family. I belong to a race of predominant people, with a predisposition for crises of anger. My father, a very good man, had a very lively character and, because of it, had
many clashes and conflicts during his life. My brother, a man of an extraordinary many clashes and conflicts during his life. My brother, a man of an extraordinary
kindness, had real anger crises. I have also inherited this irritable and dominant character. It is a mark of Russian boyars. As a child, I felt the need to hit with the chair some of the people who surrounded me. To all of these, a certain loneliness is added; I have understood it also as a way in which the world has perceived me, but also through my own conscience' (Berdiaev 1992a:21).

4.Somewhere else, he says: 'They have called me a philosopher of freedom. An obscurantist prelate has called me even a 'slave of freedom'. And it is true, I love freedom more than everything, I am born from it, it is my mother. For me, it is the primordial being' (Berdiaev 1992a:65). 5.'God wanted freedom and it was freedom that has led to the world's tragedy.
Freedom is at the beginning, but also at the end. It is, in fact, a philosophy of freedom that I have built, improved and completed all my life. I am convinced that God is present only where there is freedom and that He cannot be found outside of God is present only where there is freedom
it' (Berdiaev 1992a:65; Berdiaev 2009:35).
}

In September 1922, Nicolas Berdiaev was forced to leave forever his beloved Russia. For his departure to be allowed, he had to sign his own death sentence, accepting to be killed on the execution camp if he ever came back to the Soviet borders. (Marange 2009:14)

During his entire socialist period, he sought heroic prototypes to stimulate him in his efforts. If characters like Ibsen (1893) represented possible models for him, it is sure that the ones found in the works of Tolstoy or Dostoyevsky would be very important to him because of their status of 'suffering heroes' (Berdiaev 1992a:107). He would investigate them, trying to see how they managed to understand the world in which they lived and to overcome the problems they had to face. Speaking about them and about philosophers like Nietzsche and Marx, who influenced the first part of his life, he would show that:

Dostoyevsky, Nietzsche and Marx have had an enormous importance in the process of my understanding the dialectics of humanistic existentialism. After the interior torment, connected to the creative experience that I have been through, I have never betrayed my faith in the creative vocation of man. (Berdiaev 1950:32, 1992:272)

His readings, together with his intrinsic transformative experience, would make him realise in the end that Communism was bad and would transform him into an important militant against its crimes. His interaction with people from other cultures (Berdiaev 1992a:334-335) and the reception of his ideas would have an important contribution to this, as they helped him understand that his fight against Communism was not political, but interior, ${ }^{6}$ and that the weaknesses of the regime consisted in its spirituality, or rather on its missing spirituality.

Clearly, when one speaks about political theology and wants to see its meaning according to Berdiaev's spiritual autobiography, one must be conscious of the fact that, while in other works of this genre, like that of Dag Hammarskjöld (Morariu 2018a:1-5) or of John of Kronstadt (Morariu 2018b:1-5), there is visible emphasis on political theology because of the context and of the way in which they were presented, and in the work of Saint Silouane from Athos (Morariu 2018d:145-150) the aspect is totally missing, in Berdiaev's autobiographic work, just like in that of Maria Skobtova (Hackel 1965; Matzneff 2017; Morariu 2018c:79-81; Skobtova 1995, 2008; Smith 1965), with whom he was in contact, political theology is not an important and common topic. The philosopher prefers to speak about the political context of his home country or of his host country, insisting on elements such as human rights, the dignity of the human being, the sense of history (Berdiaev 1992a), religious reality or the interactions between philosophy and politics, rather than about political theology. Definitely, most of these aspects were simply mentioned in his autobiography because the author preferred to investigate them in detail in other works, such as A New Middle Age (Berdiaev 2001) and Spirit

6.'My fight against Communism has been a spiritual, not a political one, it has been a fight against the spirit of Communism' (Berdiaev 1992a:289). 
and Freedom (Berdiaev 2009), or in his work dedicated to the philosophy of Dostoyevsky (Berdiaev 1992b).

When he approaches questions of theology, he prefers not to mix or link them. The reason is that he considers religion a special topic and tries to avoid making political references when speaking about it. Undoubtedly, his previous experiences related to Russian reality and the fact that he came close to death because of the way he understood the spirituality of this people would also influence his conceptions about this topic.

Nonetheless, his eschatological existentialist ideas (Bagdasar 1968:298; Ivlampie 2001:5), which contributed to a different perception of time, ${ }^{7}$ let us deduce some of the elements that make his representation of the topic we are interested in. For example, in his spiritual autobiography, he speaks about solitude and communion, showing the importance of the latter for Christian life (Berdiaev 1992a):

Loneliness is an essential topic. Its opposite is communion. Isolated and in communion - this is the core of the entire religious life. How can overcome isolation, separation? Religion is nothing else than the search of reconciliation and communion. I have never had the feeling of being integrated in the objective world, the feeling of having a place in this space. I have always felt, in substance, outside the objective world, which has only touched me marginally. The absence of roots in this world subsequently determined by my philosophical way of thinking, as an objective world is at the basis of my feeling. (p. 50)

Reading this paragraph, carefully we understand the role of the Church as a place where the search for freedom comes first. This links its meaning with the political area and political theology, and helps it be perceived as a factor that helps the process of achieving this freedom and its final form - communion. Although he sees the final end of the world as the purpose and he does not refer often to the political space, he is also interested in this topic. Moreover, in the evaluation of the human being as a subject of politics and theology, he speaks about the superior nature of the human being, emphasising it (Berdiaev 1992a):

Human intuition and creative freedom have been my starting point (in creation), not Sophia or the sanctification of the flesh, as it happened with others. The evil of human life has troubled me more than anything else. This does not identify with the feeling of being a sinner, like for Calvin or Luther, for example, or like for Jansenists and in the monastic-ascetic Orthodoxy. I had the primordial sense of world's privations and misery, but I also had faith in the superior nature of man. (p. 205)

\section{Conclusion}

Although in his spiritual autobiography he does not develop the subject of political theology, unlike in some of his other works of other authors of this genre (see, e.g., Morariu

\footnotetext{
7.For, as specialists show: 'Berdiaev's philosophy is an eschatological one, therefore it is linked the pore

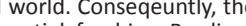
notion of redemption, like the one of salvation, is essential for him. Berdiaev deduces three categories of time: cosmic time, historical time and existential time, which is the that of subjectivity, of human eternity. The three ones tend towards eternity, which is the end of time' (Huisman 2001:106).
}

2018e:54-64), Berdiaev offers some interesting elements related to it. His ideas can be connected with others from other of his works, in which he develops his philosophical way of thinking. Likewise, his spiritual autobiography is important for this topic, among others, because he often explains the genesis of his ideas and presents them in detail, highlighting their roots. Moreover, because of his way of seeing the eschatological dimension of society and because he puts forward an interesting conception about freedom and the superior nature of man, which comes from the theological world and which can be linked also with politics, he opens new bridges of investigation and dialogue. For these reasons, among other important ones, his spiritual autobiography must be rediscovered and fructified by contemporary scientific research.

\section{Acknowledgements Competing interests}

The author declares that he has no financial or personal relationship(s) that may have inappropriately influenced him in writing this article.

\section{References}

Audi, R. (general editor), 2015, The Cambridge Dictionary of Philosophy, 3rd edn., Cambridge University Press, Cambridge.

Augustine, S., 1991, Confessions, Oxford University Press, Oxford.

Bagdasar, N., 1968, 'N. Berdiaev - filozof al istoriei [N. Berdiaev - Philosopher of the history]', Revista de filozofie 15(3), 297-306.

Berdiaev, N., 1950, An essay in eschatological metaphysics: Creativity and objectification, Geoffrey Bless Publishing House, London, UK.

Berdiaev, N., 1976, De l'inegalite, Les Editions de L'Aged'Homme, Lausanne, CH.

Berdiaev, N., 1992a, Essai d'autobiographie spirituelle, Editions Buchet Castel, Paris.

Berdiaev, N., 1992b, Filosofia lui Dostoievski [Dostoyevsky's philosophy], European Institute Press, lassy, RO.

Berdiaev, N., 1998, Cunoaşterea de sine. Exerciţiu de autobiografie filozofică [Selfknowing. Exercise of philosophical autobiography], Humanitas Publishing House, Bucharest, RO.

Berdiaev, N., 2001, Un nou Ev Mediu [A new middle age], Paideia Press, Bucharest, RO.

Berdiaev, N., 2009, Spirit și libertate - încercare de filosofie creștină [Spirit and freedom - Attempt of Christian philosophy], Paideia Press, Bucharest, RO.

Bompiani University, 2006, Enciclopedia Filosofica Bompiani, vol. 2, Bompiani Press, Milano, IT.

Casañas, M., 1982, 'L'autobiographie de Berdiaev', Revue Philosophique de Louvain, 4ieme serie 80(46), 282-288. https://doi.org/10.3406/phlou.1982.6187

Chamberlain, L., 2007, The philosophy steamer. Lenin and the Exile of the intelligentsia, Atlantic Press, Londra, EN.

Craig, E. (general editor), 1998, Routledge encyclopedia of philosophy, vol. 1, Routledge, London.

Damian, T., 2010, 'The concept of freedom in Nicholas Berdiaev's Philosophy', Analele Universităţii Spiru Haret. Seria Studii de Filosofie 12, 205-206.

Dostoievski, F.M., 1997, The brothers Karamazov, David Campbel Publishers, London, EN.

Gide, A., 1946, Journal (1939-1942), Les Editions Gallimard, Paris, FR.

Gide, A., 1948, Journal (1889-1939), Les Editions Gallimard, Paris, FR.

Hackel, S., 1965, One, of Great Prince, Darton Longman \& Todd, London, EN.

Huisman, D., 2001, Dicţionar de opere majore ale filosofiei [Dictionary of major works of philosophy], Encyclopaedic Publishing House, Bucharest, RO.

Ibsen, H., 1893, Solness le constructeur: drame en troisactes, Les Editions de Nouvelle Librairie Parisienne, Paris, FR.

Ivlampie, I., 2001, Nikolai Berdiaev şi spiritualismul rus [Nicolae Berdiaev and the Russian spiritualism], Dominus Press, Galaţi, RO.

Louth, A., 2015, Modern orthodox thinkers. From the Philokalia to the present, Society for Promoting Christian Knowledge, London, EN.

Lubas-Bartoszyńska, R., 2010, Autobiografie filozofów [Autobiographies of philosophers], Adam Mickiewicz University Press, Poznań, PL. 
Marange, C., 2009, 'Presentation', in N. Berdiaev (ed.), Pour un chrianisme de creation et de liberte, pp. 9-34, Les Editions du Cerf, Paris, FR.

Matzneff, G., 2017, Maria Skobţova - Sfântă ortodoxă victimă a nazismului [Maria Skobtova-Orthodox Saint, victim of Nazism], Renaşterea Publishing House, ClujNapoca, RO.

Morariu, I.M., 2017, 'Aspects of political theology in the spiritual autobiographies of the Orthodox space? New potential keys of lecture', Astra Salvensis 5(10), 129-133.

Morariu, I.M., 2018d, 'An interdisciplinary genre in the theological literature: The spiritual autobiography and its landmarks for the Orthodox space', Journal of Education, Culture and Society 8(1), 145-150. https://doi.org/10.15503/ jecs20181.145.150

Morariu, I.M., 2018a, 'Aspects of political theology in the spiritual autobiography of Dag Hammarskjöld', HTS Teologiese Studies/Theological Studies 74(4), a4857, 1-5. https://doi.org/10.4102/hts.v74i4.4857

Morariu, I.M., 2018b, 'Aspects of political theology in the spiritual autobiography of Saint John of Kronstadt (1829-1908)', HTS Teologiese Studies/Theological Studies 74(4), a4993, 1-5. https://doi.org/10.4102/hts.v74i4.4993

Morariu, I.M., 2018c, 'Sfânta Maria Skobtova într-o nouă lumină [Saint Maria Skbotova in a new light]', Tabor 9(5), 79-81.

Morariu, I.-M., 2018e, 'Theological ideas of Nichifor Crainic and their relevance for his political activity', Postmodern Openings 9(4), 54-64. https://doi.org/10.18662/ po/45

Pezzimenti, P., 2013, Il pensiero politico del XX secolo [The political taught of the 20th century], Rubbetino Editore, Soveria Mannelli, IT.
Rousseau, J.J., 1969, Confesiuni [Confessions], vol. 1-2, State Press for Literature and Art, Bucharest, RO.

Skobtova, M., 1995, Le Sacrement du frere, Le sel de la terre, Paris, FR.

Skobtova, M., 2008, Viaţa şi învăţăturile Maicii Maria Skobţova (1891-1945) iubirea nebună de aproapele [The life and teachings of Mother Maria Skobtova (1891-1945) - Crazy love for the neighbour], 2nd edn., Deisis Press, Sibiu, RO.

Smith, T.S., 1965, Mere Marie, nonne et rebelle, Presses de la Cite, Paris, FR.

Tolstoy, L., 1904, Desmeticiți-vă [Wake up], Press of Universal Office Ath. I. Nițeanu, Bucharest, RO.

Tolstoy, L., 1907, Correspondance inédite, Les editions du Bibliothèque-Charpentier, Paris, FR.

Tolstoy, L., 2008, Memorii [Memories], vol. 1-2, Adevărul Holding Publishing House, Bucharest, RO.

Tolstoy, L., 2013, Jurnal - ediţie definitivă [Diary - Definitive edition], European Idea Publishing House, Bucharest, RO.

Tolstoy, L., 2016, Spovedanie - căutând sensul vieţii [Confession - Seeking for the sense of life], Herald Press, Bucharest, RO.

Tolstoy, L., 2017, Despre Dumnezeu şi om - din jurnalul ultimilor ani (1907-1910) [About God and man - From the last years diary], Humanitas Publishing House, Bucharest, RO.

Vadimov, A.V., 1998, 'Cuvânt înainte. Dincolo de fruntariile cunoaşterii de sine [Foreword. Beyond the borders of self-knowledge]', in N. Berdiaev (ed.), Cunoasterea de sine. Exercitiu de autobiografie filozofică [Self-knowing. Exercise of philosophical autobiography], pp. 9-12, Humanitas Publishing House, Bucharest, RO. 